\title{
ІДЕЙНО-АРГУМЕНТНИЙ ПОТЕНЦІАЛ ЕКОЛОГІЧНОЇ ПУБЛІЦИСТИКИ (НА ПРИКЛАДІ СВІТОВОГО БЕСТСЕЛЕРА НАОМІ КЛЯЙН «ЗМІНЮСТЬСЯ ВСЕ. КАПІТАЛІЗМ ПРОТИ КЛІМАТУ»)
}

\author{
Вікторія Житарюк' ${ }^{1}$ Мар'ян Житарюк ${ }^{2}$ \\ Львівський національний університет імені Івана Франка, \\ вул. Генерала Чупринки, 49, 79044, Львів, Україна, \\ e-mail: mgzhyt@i.ua \\ ${ }^{1}$ https://orcid.org/0000-0002-3570-4521 \\ ${ }^{2}$ https://orcid.org/0000-0002-5690-5701
}

У статті виокремлено кілька найважливіших питань, на яких акцентує увагу автор книги. Це, зокрема, вплив економічного розвитку на кліматичні процеси; зв’язок між природоохоронними організаціями та нафтовими компаніями, виникнення та поширення рухів проти екологічної катастрофи. Особливий акцент на необхідності радикальних змін у суспільному світогляді.

Ключові слова: екологічна публіцистика, Наомі Кляйн, бестселер, репортаж, катастрофа, ідея, аргумент, кліматичні зміни, система цінностей.

Вступ і постановка питання. Екологічні катастрофи, які час до часу виникають у різних куточках планети, несподівані та неочікувані зміни у вже усталених погодних умовах у всьому світі спонукають до роздумів. Чи все гаразд на нашій планеті? Коли і чому щось пішло не так? Чому так часто особливо протягом останніх десятиліть природа намагається нам про щось розповісти, звернути наші погляди, зосереджені, як правило, на розв'язанні політичних, економічних чи суспільних питань, на щось суттєвіше? На те, без чого ми, як вид, не матимемо майбутнього.

Проблеми екології, незворотні кліматичні процеси цікавлять і турбують багатьох. Фахівці й небайдужі, учені, письменники й публіцисти пропонують різні шляхи їх усунення: помірковані, науково обгрунтовані і досить радикальні.

Огляд літератури й джерел. Україну спіткала екологічна катастрофа планетарного масштабу у 1996 р., коли вибухнув ядерний реактор на четвертому енергоблоці ЧАЕС. Наслідки трагедії не подолано й досі. Про неї сказано вже чимало, але одним 3 перших документальних творів була повість Юрія Щербака «Чорнобиль» [1]. Цей та подібні виступи в УРСР були піонерськими в реконструюванні стабільного і т.зв. благополучного совкового мислення з постійними «одобрямс», сприяли зародженню й формуванню екологічного мислення, пізнання та світосприйняття. Тож цілком зрозуміло, що екологічна тематика і проблематика стане важливою складовою ін-

(C) Житарюк В., Житарюк М., 2019 
формаційного простору. Ї̈̈ розроблятимуть і журналістикознавці. Можна сказати, що наша Україна внесла значну лепту в осмислення екологічних викликів сучасності. Значна заслуга у цьому й конкретних авторів (за хронологією): Олександра Коновця [2: 18-21], Мар'яна Житарюка [3: 3], Олександра Бєлякова [4; 5], Дмитра Олтаржевського [6], Ганни Гопко [7: 298-305], Таміли Бондаренко [8], Сергія Хомінського [9] та багатьох інших. Борис Потятиник та Мар'ян Лозинський своєю монографією «Патогенний текст» [10] уперше в Україні запропонували сприймати явища, факти, дійсність та оцінки крізь призму інформаційної екології. Надалі на цій основі у Львівському національному університеті імені Івана Франка був створений і успішно працює Інститут медіа-екології.

Що стосується ідейної, аргументаційної складової в журналістиці, то тут 3-поміж українських теоретиків найбільш значний посил належить насамперед Володимирові Здоровезі [11; 12] та Володимирові Шкляреві [13; 14]. Фраза проф. В. Шкляра «аргумент - основа доказовості» давно класична, навіть аксіоматична. Згодом своїми міркуваннями, аналізом, концептуальним узагальненням їх значною мірою доповнили Йосип Лось [15], Мар'ян Житарюк [16] та ін.

В умовах глобального, інформаційного світу нам доступні не тільки українські, а також і світові зразки сучасної, модерної екологічної думки. Уже третій світовий бестселер відомої канадської журналістки, однієї із ТОП 15 інтелектуалів світу за версією журналів «Prospect» (Великобританія) та «Foreign Policy» (США) Наомі Кляйн «Змінюється все. Капіталізм проти клімату» [17] повністю руйнує стереотипи про кліматичні зміни, формує якісно новий погляд на проблему і підштовхує до змін, насамперед, у світогляді кожного з нас, кожного міста, регіону, країни. Саме оригінальна назва книги «This changes everything» («Це змінює все») якнайточніше передає суть проблеми. Це - як світогляд людства, його прагнення до економічного зростання, що змінює планету протягом усього розвитку. А тепер зміни, спричинені людською діяльністю, трансформують саму людину та її свідомість.

Чи не найлаконічніші та найвлучніші характеристики українського видання, яке вперше українською мовою в перекладі Дмитра Кожедуба вийшло у київському видавництві «Наш формат» 2016 р., зробила Анастасія Нарольська: «Книга-репортаж, що не соромиться виставляти у небажаному світлі будь-кого. Відчувається нестримний, викривальний темперамент західної журналістики. I сама книга написана для нього, під нього, до нього - до Заходу, там де все відбувається, вібрує та шириться світом» [18].

Основний виклад. «Як нація, ми маємо пройти через повну переоцінку цінностей. Ми маємо швидко перетворитись із суспільства, орієнтованого на речі, на суспільство, орієнтоване на особистість», - писав Мартін Лютер Кінг Мол. у 1967 р.

Рано чи пізно людина повинна усвідомити, що вона - частина не тільки певної громади, суспільства, а передовсім - невіддільна частина природи, Землі. Завдаючи шкоду навколишньому середовищу, ми отруюємо собі теперішнє, відбираємо чисте і безпечне майбутнє у прийдешніх поколінь.

Із безлічі нагальних та важливих екологічних питань Наомі Кляйн виокремлює кілька, на її думку, найбільш вартісних і саме на них акцентує увагу.

«Наша економіка та планета перебувають у стані війни» [17: 29]. Початок масштабного процесу глобалізації, який передбачав і створення Світової організації торгівлі, і масову приватизацію на пострадянському просторі, і формування зон вільної 
торгівлі, й економічний вибух у країнах Азії, підштовхнув ще одні процеси. Прагнення досягти вищих темпів розвитку, розширити економічні сфери впливу все далі і далі, підвищити загальний рівень добробуту вимагало і вимагає більшої кількості природних ресурсів, швидшої їх переробки. Наслідком цього стає все більша кількість викинутих у повітря шкідливих речовин, підвищується рівень вуглецю в атмосфері, який підвищує і так високі показники температури повітря, які змінюють клімат і нашу планету. «Якщо температура повітря досягне певної межі, можуть початися непередбачувані та потенційно незворотні зміни, котрі матимуть масштабний руйнівний ефект. Це буде колапс, наслідки якого ми не зможемо контролювати» [17: 11].

На думку президента Індії Р. Венкатарамана, «глобальна екологічна криза стала результатом надмірного споживання розвиненими країнами природних ресурсів та індустріалізації, на якій базується їхній спосіб життя. Якби розвинені держави споживали менше, усі були б у безпеці» [17: 79].

Попри очевидний вплив розвитку економіки на клімат, у 1992 р. в Ріо-де-Жанейро підписали документ під егідою ООН, у якому зазначено, що «заходи, необхідні для боротьби зі зміною клімату, включно з односторонніми, не мусять обмежувати можливості міжнародної торгівлі» [17: 81]. Цей поворотний момент показав очевидні пріоритети. Навіть незважаючи на ухвалення різноманітних договорів, заяв екологічного спрямування, здебільшого рекомендаційного характеру, інтереси торгівлі впевнено запанували над кліматом (виділення наше. - В. Ж., М. Ж.).

Авторка пропонує глибше вивчення цієї проблеми. Вона вважає, що поштовх до ери екстрактивізму - ери споживання, безжального експлуатування природних багатств без огляду на інші, пов'язані з цим, сфери, дали ще у 17 столітті. Ф. Бекон у 1623 р. писав: «Людина не мусить вагатися, прагнучи до земних закутків, адже перейматися варто лише через правду» [17: 165]. А Земля - це машина, таємниці якої може опанувати людський розум. Його думки продовжив В. Дерхем «Якщо потрібно, ми можемо обнишпорити всю планету ...заради багатства» [17: 165]. Кульмінацією став 1776 р., коли Дж. Ватт зробив, мабуть «найважливіший винахід у сучасному світі» - паровий двигун [17: 166]. Використовуване у ньому викопне вугілля звільнило людство від залежності від сил природи, стало початком їхнього повного підкорення і встановлення цілковитого панування слабкої людини. Саме слабкої - перед потужними ударами у відповідь від природи. Людина є частиною цього світу, а не цілковитим і часто дуже жорстоким володарем.

Спалення вугілля, яке, «як природна губка, вбирає в себе багато речовин - від урану до кадмію» [17: 170], вивільняє та дозволяє потрапити в атмосферу токсинам, які поглинаємо всі ми. Тим часом саме вуглець спричиняє глобальне потепління. Який вихід із цього замкненого кола? Перше, що потрібно зробити, - зменшити, а потім і припинити зовсім, використання викопних корисних копалин: вугілля, нафти і особливо сланцевого газу. Адже застосування останнім часом нетрадиційних методів видобутку, як нібито більш екологічно доцільних, тобто - гідророзриву породи, глибоководного буріння, підземної розробки нафтоносних пісків, стає «ковадлом, яке б’є по всьому навколо себе. Коли ці удари відбуваються на поверхні землі, це видно неозброєним оком. В іншому разі ковадло націлюється на надра планети і руйнує критично важливі частини екосистеми» [17: 304]. 
Зниження темпів видобутку викопних ресурсів неминуче призведе, на думку багатьох дослідників, до зниження і так доволі низького життєвого рівня країн постачальників сировини. Тобто забираючи природні багатства у бідніших країн, розвинуті країни збільшують власні статки і залишають останніх один на один 3 бідністю і зруйнованою екологією. Тому вже починають лунати заклики: багаті мають поділитися з бідними своїми прибутками, одержаними за рахунок слабших. Країни «третього світу» затиснуті між ефектами глобального потепління і потребою боротися з бідністю. Допомога може надійти лише від держав і корпорацій, які розбагатіли завдяки такому грабунку [17: 380]. Це потрібно не тільки тому, що так буде правильно, а й через те, що від цього залежить наше спільне виживання. «Зараз дійсно має значення потреба перерозподілу статків. Люди мусять зайнятися цією проблемою, байдуже якими будуть наслідки», - писав ще у 1961 р. Франц Фенон [17: 417]. А це - кардинальна зміна світогляду, до якої суспільство поки що не готове.

Здавалося б, добре, що починають все-таки виникати рухи спротиву, для яких головна мета - захистити і зберегти нашу планету чистою. Але часто їхня діяльність доволі нечесна і брудна. Скажімо, відома організація «The Nature Conservancy» забирає у нафтової компанії територію, створює на ній заповідник для порятунку деяких видів тварин. Через кілька років вона доручає іншій компанії пробурити на цій території свердловини для видобутку газу. Відомо, що Міжнародне товариство охорони природи, Фонд охорони природи отримували гроші від «Shell»; «American Electric Power» фінансувала Фонд охорони природи. Всесвітній фонд дикої природи давно пов’язаний із «Shell», а «World Resourses Institute» має «довгострокові стратегічні взаємини з «Shell Foundation» [17: 187]. Екологічні організації вкладають кошти не тільки у природоохоронні проекти, а й у енергетичні корпорації (щороку ця цифра зростає). Тi, хто мав би захищати природу, фінансує тих, хто її знищує. Чому б і ні, коли ціна питання - не тисячі, а мільйони і мільярди доларів. У листопаді 2013 р. у Варшаві проходив щорічний кліматичний саміт $\mathrm{OOH}$, який профінансували паливні компанії. А на Саміті з питань вугілля та клімату найбрудніший з усіх видів палива розглядали як інструмент боротьби з глобальним потеплінням [17: 191]. Коментарі, зрозуміло, зайві.

Проте, попри песимізм і, здавалось би, безвихідь із ситуації, Наомі Кляйн стверджує, надія ще є. Раз по раз виникає «Блокадія» - кочівна траснаціональна зона конфлікту [17: 275]. Ї̈̈ учасники прагнуть фундаментальних змін. Вона може з'явитися у Греції, де члени Блокадії прагнуть не допустити до масового вирубування лісів і масштабного видобутку золота та міді. Чи, скажімо, у невеликому румунському селищі Пунджешть, де протестують проти запуску першої свердловини для видобутку сланцевого газу. У Канаді Блокадія виникла на землях корінних індіанців для протесту проти сейсмологічних тестів перед видобутком сланцевого газу. У сільській місцевості Великобританії - проти того ж небезпечного видобутку газу. Блокадія з'явилась у Китаї, коли пастухи повстали проти планів перетворити їхні землі на енергетичну базу країни. Блокадія дісталася навіть до борту криголама «Arctic Sunrise», коли активісти почали протест проти буріння під кригою, що тане. Появ Блокадії стає все більше і більше, а їі філософія кристалізується: «час перестати викопувати отруту з надр землі та почати користуватися безліччю джерел енергії на поверхні планети» [17: 283]. Це конструктивний рух, що активно створює альтернативну економіку, яка базується на інших принципах і цінностях. 
Саме трансформація суспільної свідомості на усіх рівнях може розпочати процес порятунку нашої планети. Людству варто відмовитися від одного 3 найнебезпечніших переконань нашої культури: «віри в те, що технології врятують нас від наслідків наших дій» [17: 239]. Потрібно негайно переосмислити всю систему цінностей. Ми любимо говорити про те, що Земля - єдина жива планета у Всесвіті, така беззахисна і прекрасна. Ми любимо уявляти себе героями - суперменами, які врятують їі. Але насправді - це люди дуже вразливі і крихкі, а Земля - здорова й могутня. Ми можемо нібито взяти в руки їі зменшену модель - глобус, а насправді це Земля тримає нас у своїх руках. Гратися Землею, як м'ячем, то підкидаючи вгору, то відбиваючи безліч разів, то закидаючи у сітку, - небезпечно. Якщо ми доведемо ії до крайнощів, вона здатна цілком знищити нас.

Людство має нарешті зрозуміти, що не «ми тут головні, ми - частина величезної системи життя, від якої усі залежні» [17: 403]. Як і кожен з нас, природа теж має права і обов'язки. Які саме? Годувати нас, одягати, забезпечувати усім необхідним. I їх вона виконує сумлінно. А ми, здається, забули про її невід’ємне право «існувати і процвітати» У гонитві за процвітанням і кращим життям ми заховали пам'ять про свій нерозривний зв'язок з природою кудись дуже далеко. I тільки тепер, перед загрозою неминучої катастрофи, починаємо потрохи згадувати про нього. Наприклад, нова Конституція Еквадору 2008 року «вперше законодавчо закріпила права природи або Рachamamy на повагу до свого існування, на відновлення своїх основних циклів, структур, функцій та еволюційних процесів» [17: 403].

Це перші кроки. Їх замало. Ми щороку продукуємо більше парникових газів, ніж попереднього, темпи зростають. Ми самі ж «створюємо для наступних поколінь світ, який буде спекотнішим, спраглішим, голоднішим і лютішим. Нам потрібна постійна кліматична революція, яка триватиме цілодобово і скрізь» [17: 412]. На думку виконавчого директора екологічної організації «Rainforest Action Network» Ребекки Таботтон, «ми мусимо пам'ятати, що наша робота полягає більш ніж у запобіганні кліматичним змінам. Потрібно дивитися ширше. Насправді мова йде про докорінні зміни в способі нашого існування на цій планеті» [17: 9].

Попри спроби змінити щось, людство робить кілька кроків і зупиняється. Ми усі - боїмося. Наші політики та бізнесмени бояться або просто не здатні втілити плани, які зруйнують основу їхньої могутності. Решта - бояться поразки, невпевнені у власних силах або переконані, що їм самим нічого так і не вдасться змінити.

Щоб здійснити цей еволюційний та революційний прорив, людство має зрозуміти помилки минулого, повірити у власні сили. «Ми здатні на більше, ніж нам казали. Ми прагнемо більшого і в цьому прагненні маємо більше союзників, ніж могли уявити» [17: 422]. Світ, який ми поступово, але невпинно нагріваємо, рано чи пізно підійде до точки кипіння. Що буде після неї - залежить тільки від нас.

Висновок. Світовий бестселер Наомі Кляйн - мабуть, найдовший відомий нам репортаж на понад чотири сотні сторінок, мовби оголює планетарний нерв, адже iï виклад, аргументи, оцінки та факти, будучи влучними, актуальними, точними i страшними, насправді не залишають людству, і журналістам у т.ч., вибору в тому, аби зайняти активну конструктивну позицію, відкинувши байдужість та апатію. 


\section{REFERENCES}

1. Щербак Юрій. Чорнобиль: документальна повість. К., 1987.

2. Коновець О. Як посилити взаємодію вчених і журналістів у висвітленні еколого-енергетичних проблем // Журналіст України. 1989. № 7. С. 18-21.

3. Житарюк М. Карпати на межі суцільних катастроф: «Круглий стіл» за участю Олега Шаблія, Валерія Петліна, Степана Стойка // Українське слово. 1992. 26 трав. C. 3.

4. Бєляков О. О. Масова комунікація та екологічна політика: Моногр. К.: ВПЦ «Київський університет», 2001. 149 с.

5. Бєляков О. О. Екологічна проблематика в засобах масової інформації: Навч. посіб. 2-ге вид., допов. і перероб. К.: ВПЦ «Київський університет», 2003. 186 с.

6. Олтаржевський Д. О. Висвітлення екологічної тематики на сторінках сучасної української преси (засади, проблематика, досвід, жанрові форми та мовностилістичні прийоми): Дис... канд. філол. наук: 10.01 .08 / КНУ імені Тараса Шевченка, Інститут журналістики. К., 2004. 196 с.

7. Гопко Ганна. Нові постановки екологічних проблем України в мас-медіа // Вісник Львів. ун-ту. Серія журналістики. 2006. Вип. 28. С. 298-305. URL: http://old.journ. lnu.edu.ua/publications/visnyk28/V28_P4_8_Hopko.pdf

8. Бондаренко Т. О. Екологічна етика журналу «The Ecologist» у контексті глобалізаційних процесів у соціальних комунікаціях: Автореф. дис. на здоб. наук. ступ. канд. н. $з$ соц. ком., спец. 27.00.01 - теорія та історія соціальних комунікацій. Харків. 2008. 29 жовт.

9. Хомінський С. Й. Огляд вітчизняної наукової літератури з екологічної проблематики в засобах масової комунікації // URL: http://journlib.univ.kiev.ua/index. php?act $=$ article\&article $=2001$.

10. Потятиник Б. В., Лозинський М. В. Патогенний текст: Монографія. Львів: Micioнер, 1996. 296 c.

11. Здоровега В. Й. Аргументація в журналістиці // Теорія і методика журналістської творчості: Підручник. 2-ге вид., перероб. і допов. Львів: ПАІС, 2004. С. 116-129. URL: http://194.44.152.155/elib/local/sk682275.pdf.

12.ЗдоровегаВ.Й.Задум, тема,ідея твору//Тамсамо. C.64-73.URL:http://194.44.152.155/ elib/local/sk682275.pdf.

13. Шкляр Володимир. Журналістський твір: структура і елементи змісту // Основи теорії журналістської діяльності (Авт. колектив: Олена Гриценко, Григорій Кривошея, Володимир Шкляр). К., 2000. С. 104-117.

14. Шкляр Володимир. Поетика журналістського тексту (змістові елементи). URL: http://journlib.univ.kiev.ua/index.php?act $=$ article \&article $=2065$

15. Лось Йосип. Публіцистика й тенденції розвитку світу. Навчальний посібник для вищих навчальних закладів III-IV рівнів акредитації. У 2-х ч.: Ч. 1. Львів: Видавничий центр Львівського національного університету імені Івана Франка, 2007. $376 \mathrm{c}$.

16. Житарюк Мар'ян. Соціокультурна модель журналістики: традиції і новаторство: Монографія. Львів, 2008. 416 с. // http://tmk-ti-vdpu.at.ua/_ld/0/30_monograf_a5_ cd.pdf 
17. Кляйн Наомі. Змінюється все. Капіталізм проти клімату / Переклад Дмитра Кожедуба. К.: Наш формат, 2016. 480 c.

18. Нарольська Анастасія. Бестселер про клімат «Це змінює все...»- для тих, хто не читає книжки про екологію // Всі книги: сайт, 2016. 21 жовт. URL: https://vsiknygy. net.ua/shcho_pochytaty/46953/

\title{
IDEOLOGICAL AND ARGUMENTIC POTENTIAL OF ECOLOGICAL JOURNALISM \\ (ON THE EXAMPLE OF THE WORLD BESTSELLER «THIS CHANGES EVERYTHING. CAPITALISM VS THE CLIMATE» OF NAOMI KLEIN)
}

\author{
Victoria Zhytaryuk ${ }^{1}$, Marian Zhytaryuk ${ }^{2}$ \\ Ivan Franko National University of Lviv, \\ Generala Chuprynky Str., 49, 79044, Lviv, Ukraine \\ e-mail:mgzhyt@i.ua \\ ${ }^{1}$ https://orcid.org/0000-0002-3570-4521 \\ ${ }^{2}$ https://orcid.org/0000-0002-5690-5701
}

In this article authors analyse the book of the well-known Canadian journalist.

It is not such a book about the nature, the climate's changes and ecological problems as we got used to know. It is another book.

The author shows another point of view on these problems. Her book tries to change people's thoughts and notions. And she succeed in it.

The authors of the article maybe for the first time in the scientific ecological journalism have analysed the problematic and thematic spectrum, studied the argumentic basis and comprehended the ideas of reducing not consumers philosophy of human existence.

The authors of an article distinguish some the most important problems, those the book's author accentuates on. This is in particular the influence of economic progress upon climate processes, the cooperation between well-known ecological organizations and big oil companies, the rise and spreading the movements against ecological catastrophe and the necessity of changes in public world outlook.

Naomi Klein writes basically about the processes in North America and Canada, but this point of view could be transferred on the whole world.

The main idea of this world bestseller is: mankind have to cardinally change it's way of life to save our planet. Our future and the future of Earth are only in our hands.

Key words: ecological journalism, Naomi Klein, bestseller, report, catastrophe, idea, argument, climate changes, the system of values. 